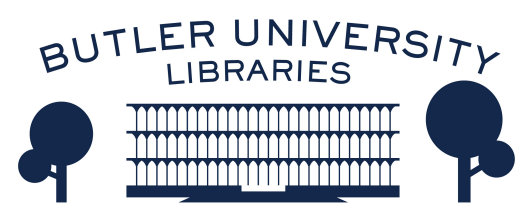

Journal of Hindu-Christian Studies

Volume 22

Article 22

January 2009

\title{
Book Review: "The Perfectability of Human Nature in Eastern and Western Thought"
}

Bradley Malkovsky

Follow this and additional works at: https://digitalcommons.butler.edu/jhcs

Part of the Religion Commons

\section{Recommended Citation}

Malkovsky, Bradley (2009) "Book Review: "The Perfectability of Human Nature in Eastern and Western Thought"," Journal of Hindu-Christian Studies: Vol. 22, Article 22.

Available at: https://doi.org/10.7825/2164-6279.1449

The Journal of Hindu-Christian Studies is a publication of the Society for Hindu-Christian Studies. The digital version is made available by Digital Commons @ Butler University. For questions about the Journal or the Society, please contact cbauman@butler.edu. For more information about Digital Commons @ Butler University, please contact digitalscholarship@butler.edu. 
2 Andrew Walls, "10 Primal Religious Traditions in Today's World," in The Missionary Movement in Christian History: Studies in the Transmission of Faith (Maryknoll, NY: Orbis, 1996), 121 (121-39).
${ }^{3}$ Sigmund Freud, Totem and Taboo.

Kristin Bloomer

University of Hawaii at Manoa

\section{The Perfectability of Human Nature in Eastern and Western Thought. Harold Coward. Albany: SUNY, 2008, 219 pp.}

HAROLD Coward has established himself over the years as one of the world's foremost experts of Hinduism and the Hindu-Christian encounter as well as a respected and learned scholar of other traditions, such as Buddhism, Judaism, and Islam. In this book he draws on all the aforementioned religions, plus philosophy, modern psychology, and yoga, to compare Western (Part I) and Eastern (Part II, with the focus on India) teachings on the possibility of human perfection, perfection understood here as the transcending of a lower ego-centered consciousness and the attainment of a state of perfect freedom, bliss, and pure awareness. What divides Western and Eastern thought on this issue, says Coward, is the general tendency of the former to regard human nature as "finite, flawed, and [of itself] not perfectible" (p. 2), thereby requiring the assistance of divine grace to reach perfection, whereas in Eastern thought there is a greater proclivity to see human nature as 1 . indeed perfectible 2 . occurring already this side of death 3. through effort alone. The author marshals and skillfully evaluates an impressive number of Hindu and Buddhist anthropologies and soteriologies to make his case, with examples taken from both antiquity and modern times.

The three basic questions that Coward puts to the different traditions are these: What exactly is understood by "human nature," what is the ultimate goal of life, and how is that goal achieved? The four chapters in the book's first half take up these themes with regard to western philosophy and psychology, Judaism, Christianity, and Islam. None of them teach that a human being by herself can reach perfection. Although great progress can be made in the development of virtue and self-awareness, there is no final breakthrough, no total annihilation of the ego, according to Western philosophy and psychology, in contrast, for example, to the teaching of Patanjali's Yoga-Sutra.

Judaism and Christianity, even given considerable variations within each of their two communities and histories, tend to agree that sinfulness and human frailty necessitate the mercy and help of God for the attainment of the final goal. Despite Jesus' call to perfection "Be perfect even as your heavenly Father is perfect" (Matt. 5:48) - salvation in Christian understanding is normally regarded as achievable only through the grace of God, Pelagius' position being the main exception. Salvation, understood in orthodox Christianity as freedom in love, is made possible only through God's antecedent unconditional love of the sinner. The perfection of this divinelyinspired human love occurs only after death in total union with God in a transcendent state called the resurrection. And so, though saintliness and holiness are possible prior to death, full perfection is not.

For Islam, as with Judaism and Christianity, the human person is understood as a unity of body, mind, and spirit. Completion of the human is therefore likewise understood as taking place in the resurrection from the dead in the afterlife by a gracious act of a merciful God. But prior to death human perfection and completion are impossible.

In contrast to the above-named Western and Semitic positions the author asserts in chapters 6, 7 and 8 (on, respectively, Indian Philosophy and Yoga Psychology; Hindu Thought; Buddhist Thought) that both Hindu and Buddhist doctrines embrace the view that human perfection, understood as a state of enlightenment and freedom from rebirth, must occur on earth in a human body, so much so that reincarnation back into the world is the necessary presupposition to ensure the 
achievability of the goal. Coward candidly notes that Ramanuja does not fall easily into this schema, since he teaches that only after death is one entirely freed from all traces and influences of karma. The entire liberative process, requiring many lifetimes, is oriented to a gradual purging of ignorance and karma, so that the human person finally awakens to her innate inner freedom and egoless consciousness. Coward, moreover, is of the opinion that "traditional Yoga psychology is seen to function in common for all schools of Indian philosophy and religion at the level of physical and mental practice in spite of major disagreements at the level of metaphysical beliefs" (p. 190). Thus the goal that we seek already lies within us, and it is there for the taking, sometimes with the help of God, sometimes not. This is a very optimistic and confident view of human potentiality.

All of this leads to the concluding point Coward makes on the final page of his book, namely that the West has mistakenly placed limitations on the perfectability of human nature this side of death. "Our - study," he writes, "leaves us with the clear dilemma that while Western thought largely judges the perfectability of human nature in life to be impossible, the evidence of the Eastern traditions arising in India is that not only is it possible, but we will each be reborn until it is realized. Is it the case that roughly one half of humanity is misled as to the philosophical, psychological, and spiritual limits of human nature?" (p. 194)

I have some reservations, nonetheless, about the way the author attempts to integrate the term "human nature" into his understanding of perfectability in the Hindu and Buddhist contexts.

To invoke Patanjala Yoga as espousing the perfectability of human nature does not seem to me to express well the teaching of the YogaSutra. It seems clear, if one examines Patanjala Yoga anthropology and soteriology, that human nature cannot be perfected nor is it desirable to seek its perfection. The real goal of classical yoga practice is to divest oneself of the delusional notion that one is, finally, in any ultimate sense, human at all. Yoga practice gradually unmasks the illusion that the human mind and the human body have anything to do with authentic identity. Recent commentaries on the Yoga-Sutra by Gerald Larson and Edwin Bryant have especially emphasized this as well as the now classic commentary of Gaspar Koelman from forty years ago. And so, from the Christian point of view, one might argue for a deficiency in any view of perfectability, such as that found in the Yoga-Sutra, in which the human dimension is transcended and left behind altogether. This was a point Paul Hacker made about Hindu anthropology some decades ago. According to Christian theology, whether Protestant, Catholic or Orthodox, the human person in her entirety as this unique historical human being and no other is perfected and completed after death.

What Coward is, in fact, doing, it seems to me, is making a strong case for certain experiences of interior liberation that are possible already now in the human body. He argues well for a degree of ego-annihilation that is not considered possible in western thinking. Ramana Maharshi is one of the most powerful examples of this kind of living liberation, of Self-realization. But spiritual attainment in the sense of inner awakening is not the same thing as affirming the value and completion of the human person in her totality, in the face of death. The transformation of the human, whereby human identity is retained and elevated in the final state of perfection, after one's time on earth has ended, does not seem to me to be regarded as the cherished final goal of either Hindu or Buddhist soteriology.

And so, despite some reservations, I am grateful to Harold Coward for raising awareness about fundamental differences in. Western and Indian attitudes about the degree of spiritual attainment that is possible in the human body. His is a most stimulating and provocative book that I hope will lead to further monographs by other scholars.

Bradley Malkovsky

University of Notre Dame 